\title{
Odysseus and a Phoenician tale
}

Russell J.R.

Harvard University, Massachusetts Hall, Cambridge, MA 02138

For citation: Russell J.R. Odysseus and a Phoenician tale. Vestnik of Saint Petesrburg University. Philosophy and Conflict Studies, 2018, vol. 34, issue 2, pp. 233-250. https://doi.org/10.21638/11701/ spbu17.2018.208

The question of the authorship of the two Homeric epics - whether there was one Homer, or two - has vexed scholars since the inception of critical literary study. The more bellicose, less inner and mysterious Iliad was by far the more popular poem in antiquity. And although the later Aeneid of Virgil tendentiously fuses together war and nostos (homecoming), it is of arms and a man, not a man of many ways and wiles, that the Roman poet sings. Odysseus is likened, invidiously, to a Canaanite (Phoenician) traveling merchant in his flexibility and adaptability - he, the "rootless cosmopolitan" of his remote age, resonates with the predicament of alienation of modern man and with the psychological depth of the modern literary sensibility, then bellicose, candid, limited Achilles and Aeneas. It is proposed in the article that the Odyssey employs the topos of a man traveling in search of lost members of his family, with a happy resolution, that seems indeed to have been peculiarly popular over many centuries with Phoenicians and Carthaginians. The author suggests indeed that Menaechmus, the name of a character in a play based on this topos with a Punic setting that might even have been performed, in a Northwest Semitic translation in Qart Ḥadašt (Newtown, i.e., Carthage) itself, is merely the very common Hebrew name Menachem. And it is noted that the topos recurs, employed in aid of religious propaganda of the Jewish Christians, in the setting of the PseudoClementine Recognitions.

Keywords: literature, tale, culture, man, topos, Christianity, paganism.

It's about family, stupid!

The Lost Boys 2: The Tribe (Thunder Road

Pictures, Hollywood, California, 2008)

\section{Two books and two Homers? What is the canonization of a sacred text?}

Homeros hebraïzōn? Kyrie eleēson! Homer acting like a Jew? Lord have mercy! Not again. The search for affinities between Homer and the Bible, between the ancient civilizations of Greece and Israel, between Athens and Jerusalem (pace Tertullian) seems to be old news: in 1658 Zachary Bogan in his Homerus Hebraizon compared words and phrases in the Hebrew Bible and Greek Epic. And the vexed question of the authorship of the Iliad and Odyssey is very much older, going back to Hellenistic literary criticism, though in this instance the question at issue resolves into a simple opposition: some believe Homer (or somebody else who was or wasn't named Homer) composed both heroic epics; others,

* For my Mother, Charlotte Sananes Russell (Rachel bat Yosef), and in memory of our ancestors from Salonica, Greece - the Jerusalem of the Aegean.

(c) Санкт-Петербургский государственный университет, 2018 
the khorizontes (lit. "separators"), that the authors were different (two poets who were not Homer but whom posterity named Homer, two different Homers, or a Homer and someone else who wasn't, etc.). Assigning an approximate date to the poems poses a further problem, though it is generally accepted that the Iliad was the earlier composition. The plot of the whole narrative is the simplest support for this supposition - first there was the Trojan War, then Odysseus got home from it - but there are other factors as well: the archaic elements of the Iliad are strong, while much of the setting of the Odyssey is that of roughly the eighth century BCE. Neither of the two poems reflects fully or accurately the Mycenaean age in which the war is set; and some of the inherited detail that the poet does know is so remote to his own time that he misunderstands it.

There seem to have been two different books from the start, however one may resolve, or fail to resolve, the question of authorship. The parties of dividers and unifiers have, thankfully, to do with authors, and not with whether an original, single book was split in two. The evidence of the proportion of surviving manuscript fragments shows, incontrovertibly, that the Iliad was read by itself and was by far the more popular of the two epics in antiquity - there are about ten times as many surviving fragments as there are of the Odyssey. It is generally accepted that ancient Hellenic scholars established a canonical text, the edition of Athens in the golden age of Peisistratus. This is over half a millennium before the books of the Hebrew Bible were canonized as the Masoretic ("traditional, handed down") text of the "written Torah" with the accompanying "oral Torah" of the Mishnah (lit. "repetition", a code of laws compiled by the Tannaim around the $2^{\text {nd }}$ century CE not directly based upon the Pentateuch but intended to elucidate it) and the Gemara (lit. "completion", the oceanic commentaries, narratives, and discussions of the Amoraim of the Land of Israel and Parthian and Sasanian Mesopotamia, anchored on the Mishnah). Mishnah and Gemara together constitute the Talmud, or "teaching". There were schools of different sages - those of Hillel and Shammai are the most prominent - that offered different interpretations and judgments, and debated each other. The Talmud records these, often without concluding who was right. The sacred books of the Zoroastrians were codified around the $5^{\text {th }}$ century CE by the Sasanian priesthood and its academies as the Avesta with its accompanying translation and commentary, the Zand. Very little of the 21 great divisions of the Sasanian Avesta survives, compared to the Talmud (which also has many subsidiary texts, also of great antiquity). But the Iranians, too, had schools following sages with differing interpretations. Even though Zoroastrians privilege orality over writing, which would suggest there were fewer written copies of the Avesta than there were of the Talmud, perhaps there was still a vast manuscript heritage that has now been irretrievably lost ${ }^{1}$.

\footnotetext{
${ }^{1}$ Zoroastrian texts in Middle Persian lament the destruction of sacred manuscripts, and the murder of Magi - the living books of the faith - by Alexander; and they record, too, the synods convened by Parthian and later Sasanian monarchs to codify the Avesta. Because of their predominantly oral tradition the Zoroastrians, like the Hindus and Buddhists in India, did not gain unambiguous recognition and protection under Islam as an Abrahamic "people of the Book", and were subject to sporadic persecutions that became increasingly severe down to early modern times. Christian states accorded Jews a protected but degraded status as an object lesson: this is what happens to Christ's people when they do not accept Him. The Talmud, which contains some anti-Christian remarks, was often censored or burnt. But its real fault is that it is the brilliant representative a living, spiritually and intellectually vibrant faith that neither has nor needs any reference or relationship to Christianity at all.
} 
In the Greek case there never seems to have been a system of sacerdotal academies devoted to commenting upon and arguing about a Homeric scripture, for all the immense importance accorded these foundational texts of Greco-Roman civilization. Neither Iliad nor Odyssey pretends to offer the two categories of authoritative, revelatory teaching that Christians, Jews, and Zoroastrians have come to expect holy scripture to offer: first, an explanation of how and why the physical universe we inhabit came into being (cosmology); and, second, normative precepts about what we human beings are supposed to do while we are in the universe, and, indeed, why it is that we are here at all (ethics). It is not the Word of one God. Yet pagan tradition assigned sacred status to both poems, the Iliad and the Odyssey, without these desiderata. Despite the misgivings of some literary critics, the consensus of the ancients was that the two poems had a common author, Homer, a blind bard from the island of Chios, just off the Ionian coast from Smyrna. The subsidiary Homeric hymns, composed after his time, became attached gradually to the venerated literary corpus. These expand upon or flesh out the events and personages of the poems. This formal process is analogous, mutatis mutandis, to the treatment in Jewish tradition, alluded to above, of the texts that have come to constitute the Hebrew Bible. The five books of Moses - the Pentateuch - at its core were taken to have been set down by a single hand, despite their obvious differences of period and authorship; and as the Masoretic canon was established, subsidiary texts were included or rejected, sometimes for reasons that are far from clear today. It takes special pleading to justify the inclusion of Ecclesiastes, whose dismal theology is on the face of it incompatible with the rugged, ethnocentric covenantal cheer of Rabbinic Judaism. And the erotic Song of Songs can be justified only if the interpretation of the whole as a spiritual metaphor is forced upon the text. The evidence of an Egyptian precursor surely argues the artificiality of such an undertaking. In the Greek case there is a similar oddity, a kind of parody in heroic verse of the Trojan War called the Batrachomyomachia, "The War of the Frogs and the Mice", in which the little creatures, with Homeric names, squeak their speeches and battle nobly for possession of a swamp ${ }^{2}$. Perhaps the ancients, in Athens and Jerusalem alike, did not take themselves too seriously, allowing room even in a pious conception of the world for humor, sarcasm, and eroticism.

The Homeric epic, consisting of two poems, 24 books in length each, is a linear narrative about the Trojan War and the return of the hero Odysseus from it. If one were to combine the two poems into a single book, a good title might be War and Peace, had not a later writer already used it. It at least presents a unity of subject, theme, genre, and character to which the Hebrew Bible, the Tanakh, cannot aspire unless one sum up the latter in the most general way as a grand narrative of the Creator's covenantal bond with His people Israel. The journey of the Torah would then include many stops along the road to survey the way, take in the view, and examine the smallest details: to specify laws, sing praises, recount the deeds of kings, and issue prophetic warnings. This approach requires a base line of irrational faith (or supra-rational faith, depending on one's point of view) requiring that one accept the canonical text in its entirety, with all its obvious textual and

2 This strange poem can be related to the larger and more familiar genre of Aesopian animal allegories. The late $17^{\text {th }}$-century Armenian poet and artist Naghash Hovnat'an (Jonathan the Painter) employed the venerable allegory of cat and mouse (cf. Art Spiegelman's graphic novel of the Holocaust, Maus, in recent years) in such a composition: the little Armenian mice think the tyrannical cat, presumably a Muslim Shah or Sultan, is dead. They rejoice, and prepare to bake a funeral loaf. But the cat rises suddenly and, loading himself with heroic epithets appropriate to the exploits of felines, boasts that he will chase them from Karabagh in the Persian east to Marsovan in the Turkish west and eat them all — see [1, p.41-42]. 
other contradictions to be accounted for as emanating from beyond time and space - that one profess the Torah as the Word of God from Sinai, that being unifying factor enough (which privately as a believer, this writer freely admits that he does, though the mundane realm of philological scholarship presents quite other parameters and demands). Credo quia absurdum est. For a clear-eyed Athenian thinker, of course, there is a fair measure of the absurd in Homer's semi-divine personages, talking horses, animate rivers, and indecorously squabbling gods: fair game for euhemeristic and metaphorical interpretation, but dangerous ground for the disbeliever, too, if one regards the trial of Socrates, with its accusation of atheism, as an expression of genuine outrage at blasphemy rather than just a trap set by his political enemies.

Part of the problem that arises when one attempts to draw a comparison between the revealed texts of the Abrahamic and pre-Islamic Iranian faiths and the sanctified Homeric corpus is the tacit presupposition that they fall under the same rubric of something one can define as "religion". This is misleading: Greco-Roman paganism evades the Judeo-Christian understanding of religion. It is not a tidy matter of a single dogma, with a more or less canonized set of customs and liturgical rites, but rather a mass of local beliefs and diverse practices sanctified by time and custom, of corresponding loyalties steeped in emotion and blended with the supernatural, all of it bound together by the sense of a larger, shared history and way of life. This complex or web of mythologies, local shrines and gods, and varied rituals was susceptible to be sure to the interpretations and speculations of philosophers, but in practice it was still to be maintained in all its manifold forms, a kaleidoscope with the sense of one light shining through but with no less a devotion to the myriad patterns and colors. The Homeric poems are not, then, normative: there are no Ten Commandments there. But they are formative: they present society with a shared vocabulary, a corpus of cultural Gemeingedanken. And they are exemplary: they display models for imitation on various levels of art, of action, and of thinking ${ }^{3}$. Out of the Homeric sea flow the intricate rivulets of the Odes of Pindar, the turbulent streams of Greek tragic drama, the rich eddies of mythography. But what do these poems, of such extraordinary importance, say?

\section{The story}

And even before the story they actually tell, where did it begin? - as Roberto Calasso is wont to ask in his long meditations on classical Greece and Vedic India. It is a wry question, since there is nearly an infinite regress till we get to the beginning of the story, and in any case Homer does not tell us the beginning (his brief is not Genesis). This is partly

${ }^{3}$ For a discussion of these three categories in the context of a canon of sacred scripture, see [2, p. 3]. The clearest case of the Homeric corpus as exemplary scripture is that of the Aeneid of Virgil, which takes up the Homeric narrative at the fall of Troy and then presents a sort of Homer-in-reverse: The Trojan exiles, led by Aeneas, journey outward to the war for the conquest of Italy that closes the epic. But Italy is obscurely their original home; so the journey is actually a nostos to a divinely promised land. It is likely here that the Roman poet appropriated both the Biblical Exodus and the idea of the Chosen People to his tendentiously propagandistic celebration of the Augustan imperial project. The shield of Achilles, evoked by Homer, is a charming, poignant cosmogram of the dance of life, but that of Aeneas is a carefully plotted political map, its message of universal Roman dominance as gravid as the metal of its manufacture. The first line clangs as dismally a gladiator's sword: Arma virumque cano, "I sing of arms and a man." Pious Aeneas is the consummate paterfamilias, but the Roman poet still reserves his derision for Odysseus, for reasons we will presently propose. 
because in his dramatic and narrative brilliance he prefers to plunge in medias res, to stress a point, rather than cover a whole tale; and partly too because he can be confident that his listeners (or readers) already know at least the outlines of the Trojan War, and probably many details. The point is not merely to retell it, but to relive it. But here is how it began: Agamemnon, king of Mycenae in the Peloponnesus, summoned the Greeks - called Achaeans or Danaans (the later Greeks - the latter is a Roman term - called themselves Hellenes) - and raised an armada to invade Troy (or Ilium, as it is also called) because its prince, Paris (or Alexander, as he is also called, not to be confused with the later Macedonian world-conqueror), had run off with Helen, the wife of Agamemnon's brother Menelaus. It is a matter of honor and shame: it is not her beautiful face that launched a thousand ships (pace Christopher Marlowe), but the embarrassing fact that she is stolen property. And the ill-fated seduction goes back to a choice of three apples, and the golden, treacherous goddess of love, Aphrodite. One recalls a much earlier epic, that of Gilgamesh, and the ruin that followed his refusal of the love of the goddess Ishtar ${ }^{4}$. Such, we are meant to feel, is the human condition: as some American men still say of women (when there are no women present), you can't live with them but you can't live without them. How much more is it true of these vindictive, fickle goddesses ${ }^{5}$. Helen's elopement will end with the destruction of Troy: Menelaus returns with her to Argos, to a tense and embittered married life in middle age made tolerable only by her spiking her husband's drinks with a drug that brings on oblivion. It is worse still for Agamemnon, who sacrificed his daughter Iphigeneia (whose name means "engendered violently") to get of the gods fair winds for the invading fleet. He is to return to his wife Clytemnestra, who detests him for his cruel deed and his selfish, callous pomposity. She and her lover Aegisthus will kill him while Cassandra howls her worthless prophecies before her own throat is cut. And because of that, the slain king's son Orestes will take revenge for his father, killing his mother. And for that, his mother's vengeful spirits, the Erinyes or Furies, will pursue him.

When Orestes reaches Athens, its patron goddess and its primordial king will grant him sanctuary, and establish law and justice in the place of the sanguinary chain of vengeance. None of that will save the House of Atreus, though: Agamemnon led the Achaean armies and fought a ten-year war, all for his family to vanish utterly. All this we have thanks to retrospective storytelling in the Odyssey and to the dramatic expansion of the narrative in the Oresteia trilogy of Aeschylus, who modestly averred that his plays, written for the annual festival of Dionysus on the slopes of the Athenian acropolis, were mere scraps from Homer's feast. So there are stories that come before, and others still of what came after, into which the narrative of the war itself is sandwiched. And this seems to be

4 The ancient Mesopotamian epic is recognized as one remote ancestor of the Homeric corpus, and it is fascinating to trace both the changes and the lines of continuity from Mesopotamia to Greece. The character of Gilgamesh seems to bifurcate: as the grand and lustful king, who leaves none of the girls and boys of Uruk in peace, he prefigures Agamemnon, with the latter's fatal lack of self-control. As the brave companion and lover of Enkidu, Gilgamesh foreshadows Achilles, with his therapon ("caretaker") Patroclus.

5 And there is no escape. The poor adolescent Hippolytus (his name means "destroyed by horses"), afraid of his own nascent sexuality and repelled by the advances of his stepmother Phaedra, sublimated his desire into hunting and racing his horse-drawn chariot. Esteeming Artemis, he succeeded only in enraging Aphrodite: a bull rose from the sea, spooking his quadriga, and he fell and was trampled and mangled destroyed by his own horses indeed. So for the Greeks the archetype of the dying and rising god - Anatolian Cybele and Attis, Hebraic and Islamic Zuleikha and Joseph, Iranian Sudabeh and Siyavakhsh (which means "black stallion"; cf. Hippolytus) - was not a basis for a cult but the occasion intricate psychological investigation of the paradoxes of sexuality. 
a large lesson of the first Homeric poem: humans being what they are, at a remove from other natural beings on the one hand (as Homer insists in his long similes, trees burst into leaf anew every spring, but we live once, then die forever), and from the gods on the other ${ }^{6}$, it is inevitable that we will go to war, and it is a foregone conclusion besides, that however necessary a war may be, in the end it will cause tremendous destruction without solving anything of our predicament, at most serving as the turning point where one epoch ends and another begins. In epic, the war generally marks the end of the heroic age and the inception of the one in which we lesser mortals live now ${ }^{7}$.

The action that drives the Iliad, which begins in the ninth year of the ten-year-long war, is a kind of abduction of Helen in miniature. Agamemnon has taken a concubine, Chryseis, from a priest of Apollo, who calls down a plague upon the Achaean camp. To lift it, the king returns the girl - but then takes another, the concubine Briseis of his champion fighter, Achilles. If Achilles were truly subordinate the problem might have ended there; but as Prof. Nagy pointed out in his seminal work, both king and warrior are called the best of the Achaeans, and the problem of such a superlative is that it cannot be plural. Achilles refuses to do the one thing he is good at, fighting, and the tide of battle begins to turn against the Greeks. The hero, brooding in his tent, muses vaguely about returning to his wife and son and aged father in "fertile Phthia", but it would have been a dim life, lived out in meaningless obscurity. The only possibility for him is to acquire klewos aphthiton, "imperishable fame" by fighting - and dying young. Achilles arrives at a kind of apotheosis towards the end of the Iliad, when he finally goes to war, slaughtering so many Trojans that Hades screams aloud; and the poem will end soon thereafter with the walls of Troy still not breached, but with its champion Hector (who name means "defender") dead, his wife Andromache widowed, his son Astyanax orphaned, and his father - king Priam bereft and undone.

\section{Enter the hero}

So the Iliad deals mainly with men. Women figure as pieces on the chess board of politics (Helen), or as objects of men's animal lust and acquisitive pride (Chryseis, Briseis, Cassandra). And the Achaean host spend their time in the company of other men, engaged in the single art of fighting, then feasting and boasting after each round. The family life of the warriors is either irrelevant to who they are, or a dysfunctional mess. Hector,

${ }^{6}$ Not that being a god would help very much: the members of the Greco-Roman pantheon are seldom worth emulation and are best offered due reverence, at a safe distance. Athena, patroness of both Odysseus and Telemachus, would seem to be the shining exception. The poetess Sappho observed that we know death is a bad thing because were it otherwise, the gods would have taken it, too, away from us. The fleeting joys of life are the best we can do; and perhaps the immortal glory of some brave deed may outlive us. But the soul flees at death to the mournful shadows of Hades. If you were a hero in this life, there will be fields of asphodel and horses to ride, which sounds as though it might be nice.

7 Thus, the apocalyptic war between the Pandava and Kaurava clans of the vast Indian epic Mahäbhärata is to usher in the basest of the epochs of history, the one we are living in now, Kaliyuga. The Bhagavad Gìtā (literally "Divine Song"), coming at exactly the midpoint of the Sanskrit text, is a teaching of the avatar (incarnate god) Krishna to his friend, the warrior Arjuna: since the latter's cause is just he must fight without regard to the long-term consequences of his actions, reposing his faith instead in God. This doctrine of yoga ("yoking", cf. the Jewish concept of the faithful believer assuming the 'ol haš-šämayim, "yoke of Heaven") and bhakti ("devotion", cf. perhaps the Hasidic concept of deveqūt, "clinging" to God) makes of the Gìta an overtly religious treatise, possibly a later interpolation into an otherwise less religiously oriented epic text. The Indian epic has an ancient Iranian analogue: see [3, p. 17-35]. 
a happy family man, is compelled to fight because of his lazy, voluptuous brother Paris' unrestrained lust - and Hector's family are all doomed. There is one hero in the Iliad for whom war is a distraction from life, who is there only because he has to be, and who just wants to get the whole damned thing over with so he can go home. This is Odysseus, who does not shrink from covert warfare, from a nocturnal commando raid in which a prisoner, Dolon, is captured, promised safety, interrogated, and then executed on the spot. This is not the honorable mode of fighting of a warrior for whom killing is a profession wrapped in traditional manners, but the way of a man who wants to win as soon as possible, by any expedient means. It is Odysseus who with the same motive - winning, destroying Troy, and leaving - acts as an adept politician and deal-maker, fixing the rift between Achilles and Agamemnon so that the Greeks can end the stalemate and fight effectively.

Odysseus is a family man who can relate easily to women, including witches (Circe) and goddesses (Athena): he misses his wife Penelope and his son Telemachus, and wants to get home to them, to Ithaca. The return voyage (Greek nostos) will take ten years and 24 books, also starting in the ninth year of the ten - a kind of parallel, chiastic complement to the war itself. For the first poem is an outward campaign of a mass of soldiers with the goal of invading and destroying an entire city; while the second, a single man's journey back home to restore a little kingdom and reunite a sundered family, is in more than one sense a reversal of the first.

The disparity between the Iliad and Odyssey is thus profound, for all their many stylistic and other points of similarity. This difference has encouraged khorizontes to the present day, but one thinks it a weak point of argument, whatever the others. For it can be argued with equal persuasive force that the very inverse symmetry of the two narratives is evidence of a literary strategy most likely to have been conceived, and achieved, by a single ingenious author. And where the two poems differ greatly, surely that has to do in large part with their very different settings, and concerns - and a good writer can and does compose different books, not rewrite the same one. (In Western Armenian one would say of such a bad writer, Meg lari vra gĕ khagha, "He plays on one string.") The authoritative Homeric scholar Prof. Gregory Nagy has deftly defined a key difference, in terms of the focal characters, between the two poems. Achilles, the best of the Achaeans (a wry definition, also achieved by Nagy, to be approached again presently), the central figure of the Iliad, is a man characterized by bie - of strength and violence; while the defining term for Odysseus is meetis - reasoning and thought ${ }^{8}$. The first line of the Iliad asks the goddess to sing the mennis, "anger", of Achilles; in contrast, the opening verse of the Odyssey asks the Muse to tell of a man "of many ways" (polytropos) - elsewhere Odysseus receives the epithet polymennis. As a corollary to this, one might focus on the family: for Odysseus it is everything, worth a journey of return (Greek nostos, "homecoming", cf. the loan in English, nostalgia) and of recognition of one's genuine identity that will take many years. For Achilles family means nothing, it would take but a few days to go home, and identity is bound up with fame achieved on the battlefield among fellow soldiers. He is a man with one tropos, one skill (tekhnē) and one sphere of excellence (aretē) only: he is a warrior. And we have already seen that even though Menelaus and Agamemnon do get home, the ends of their nostoi are meaningless: long and unbearably miserable for the former, and short and hideously violent for the latter.

\footnotetext{
${ }^{8}$ Cited by [4, p. 622].
} 
Odysseus, by contrast, can try on different identities, thrive in different environments, practice many trades, and transcend his class, his station, even his gender - at one point he cries like a woman. He is a fine, careful carpenter, seemingly more at home with tools than with weapons, though he can use both well ${ }^{9}$. He has to adapt, to dissemble, so often that the reality of his very name seems to dim and waver, after he declares himself to the cyclops Polyphemus as Outis, "Nobody", in order to avoid pursuit. His homeward voyage is one of recognition, a theme whose dramatic importance we shall discuss presently. And at one point Odysseus is told, not kindly, that "you seem to be a skipper of a merchant crew rather than a trained athlete" (see Odyssey 8.145-164). A cosmopolitan, a trader these are well-known anti-Semitic stereotypes and it is no wonder that James Joyce called his novel about the peregrinations through Dublin of Leopold Bloom, a Jew, Ulysses (the Latin form of Odysseus, from a western Greek Oulixēs). But there was another people, close cousins of the Israelites, who were renowned as seafaring traders. And it is a possible affinity of the Odyssey to their culture that we shall now explore.

\section{The Phoenicians}

Homer calls the Phoenicians "Sidonians", after one of their two principal home ports in the Lebanon; the other, Tyre, overtook Sidon in importance during the reign of Hiram I (969 BCE). The Greek word phoinix can mean purple (the famed Tyrian export), or date palm (a Phoenician national symbol), or a mythical bird that is immolated in fire and rises. But they always called themselves Canaanites: $k n^{i} n$ is of unknown origin but came to be associated in Biblical Hebrew with the meaning of "merchant" since that was the calling par excellence of the Phoenicians. The Semitic root $m k r$ is found in the Akkadian designation of the upper class tamkäru-traders, Phoenician clients. Later, Carthaginian traders were known as $m k r$ and $s h r$; commercial agents, as $m h s b m[6, \mathrm{p} .107,229]^{10}$. There was extensive contact between Hellenes and Phoenicians from the Mycenaean age on (from the $14^{\text {th }}$ century BCE), and Linear B has some Semitic loans that may be Phoenician (a Northwest Semitic language so similar to Hebrew that the two are mutually intelligible most of the time): kurusu for "gold", cf. Hebrew hārūuss; kito "robe" (Classical Greek khitōn), cf. Hebrew kitonet. Phoenicians colonized Cyprus in the late $10^{\text {th }}$ century BCE; a bronze bowl of the $9^{\text {th }}$ century of Phoenician manufacture was found at the Kerameikos, Athens. Major Phoenician expansion into the western Mediterranean began in the $8^{\text {th }}$ century; and descriptions in the Odyssey of Phoenician objects relate to this period as well, and not the Bronze Age ${ }^{11}$.

In around $814 \mathrm{BCE}$ the Tyrian princess Elissa or Dido (the name means "wanderer", sister of Pygmalion and husband of Acherbas (Zakarbaal, meaning "the Lord remembered him"), high priest of the temple of the "Tyrian Heracles" Melqart (the god's name

${ }^{9}$ Odysseus returned home in the hope of a peaceful life, but had to massacre the suitors of Penelope and some of the serving-women of the palace - their collaborators - in order to regain control of his own household. This part of the narrative has specific parallels in other epics in Indo-European languages, at the point in the story where a king must assert his right to his wife's bed: see [5] on the case in the Armenian Artaxiad cycle and the Ossetian (Alan) Narts.

10 Punic (Carthaginian) inscriptions mention "sellers" ( $m k r$; cf. Hebrew mōker) of iron objects $(b r z l)$, gold objects $(h h ̣ r s ̦)$, broad beans $(h p l)$, and flax or linen $(h p s ̌ t)$; two Punic inscriptions mention sḥr, "merchants" (cf. Hebrew sōhar). See [7, p. 281-282; 341-342].

11 See [8, esp. p. 46-51]. 
means "king of the city" in Phoenician), founded the city of Carthage (Qart Hadašt, "New Town") on the Tunisian coast, directly south - as the frightened Romans always reckoned its position - of the mouth of the Tiber. It was to outgrow and outlive the home of its founders, as the capital of a naval and commercial empire, till its conquest and destruction by the Romans in 146 BCE. In the Aeneid, Dido seduces Aeneas when his band visit the new town on their way to Italy, and would have him stay on with her. But the hero, true to his mission, abandons the lustful queen, who combines the dangers of Circe and Calypso and the voluptuous blandishments of the dangerous, deceitful Orient with a political challenge - if Rome is to thrive, then Carthage cannot. As the Trojans set sail, Dido swears eternal enmity, has a pyre built on the acropolis of Carthage, the Byrsa, with her bed on top, and immolates herself. Hell hath no fury, perhaps, like a woman scorned; and although Virgil doubtless makes an invidious contrast between the manly self-control of Roman Aeneas and the violent, effeminate hysteria of the Carthaginian monarch, her act was historically consonant with Phoenician religious practice ${ }^{12}$. For the Romans henceforth, whatever was Phoenician was Carthaginian, and the term for the Phoenician language became Punic.

There are but two references in the Iliad to the Sidonians: Paris brings an embroidered garment from Sidon to Troy, and there is a silver krateer (mixing bowl for wine) made by the sidones polydaidaloi "skilled Sidonians" [4, p. 598]. They do not figure, that is, except as producers of the sumptuary objects enjoyed by royalty. But in the Odyssey the Phoenicians are mentioned more often, and generally in a negative way - not as admirably polydaidaloi but as deplorably (though alliterative) polypaipaloi, "devious" [4, p. 621]. Odysseus, ever the master of creative cover stories, tells Eumaeus, the "glorious swineherd" who welcomes him and keeps Telemachus and him well hidden from the suitors on Ithaca as they plot their coup détat, that he was tricked by a Sidonian sea captain hungry for profit who took long voyages. Eumaeus has his own tale of woe and abduction by those polypaipalous people, whose ships are slightingly dismissed as crammed with athyrmata, cheap trinkets (Ody. 15.459). (The Phoenicians in fact excelled at producing and selling mass-market knock-offs of Egyptian art. But they also transported other goods, often quality items, back home from the places they sailed to: Ezekiel 27 mentions Tyrian ships with goods from Yavan, i.e., Ionia, Greece.) Athena Herself on a visit to Telemachus pretends to be the Taphian merchant Mentes, and thus also a Phoenician, if Prof. Irene Winter's suggestion that Taphian is a portmanteau name for a fictional place, combining Cypriot Tamassos and Paphos, is correct [4, p.613, n. 13].

Perhaps the reason the Iliad scarcely mentions the Phoenicians, if only as the source of luxury goods, is that they are best known as traders and travelers and are thus not relevant to the epic's setting or characters, as the poem focuses on the aristocratic way of life of a landed royal and warrior elite. In the Odyssey, however, Phoenicians are mentioned more often, and precisely as voyagers and merchants with sea voyages that were, like Odysseus', very long, lasting as much as three years [4, p.605]. One thinks that this might be because they can thereby serve as a kind of foil for Odysseus' predicament and the anxiety caused over the loss of his own status and identity over time. He is different from, but in character and predicament also uncomfortably close to, these Sidonians and this juxtapo-

12 Elissa actually committed self-immolation, an act alien to the Classical world but commonplace among the Canaanites, in order to remain faithful to Acherbas and refuse the hand of the Libyan chieftain Hiarbas. See [6, p.215-216]. 
sition of the hero with the near other contributes to narrative tension ${ }^{13}$. When he finally does arrive home, will all this traveling, and negotiating, and role-playing, have changed his identity into that of a Sidonian? Thomas Wolfe wrote, You can't go home again; for, as his contemporary George Seferis, the Modern Greek poet, sighed, partly with Odysseus in mind, Ma den teleionnan ta taxeidia, "But the journeys never ended."

If the structure and story-line of the Odyssey differ in so many ways from those of the Iliad, and the latter, rooted in archetypal and familiar epic themes, was the poem GrecoRoman posterity preferred, then we might search for the origin of the story of the Odyssey outside Hellenic, even Indo-European sources. I will presently propose here such a source. It is Phoenician and is attested at least thrice to my knowledge, albeit after the time of Homer. But the fact that it was told over and over, and used for different purposes, suggests it was both traditional and popular, and might therefore have been very old, too, perhaps current when Phoenician power was at its zenith and Greeks and Sidonians lived and worked in close proximity. The first issue to be considered is the evidence for the existence of a Phoenician literature in the first place. Though literature can thrive in oral form without most of it being set down in writing (pre-Islamic Arabic is a good example for the otherwise hyper-literate Semitic world), ancient Phoenicia lay between the two great ancient cradles of written civilization - Egyptian and Mesopotamian - and papyrus came from Phoenician Byblos (hence Greek biblion, "book", and the "Bible"). So did the alphabetic script used by most of the human race today. Even though very little of Phoenician literature has survived, it is likely there was once a very substantial body of writing in the language.

Speakers of a Northwest Semitic language modified Egyptian phonetic characters to create the first alphabetic script, in the $2^{\text {nd }}$ millennium BCE. Subsequently the Phoenicians reduced and reshaped the alphabetic Ugaritic cuneiform signs, employing forms of the earlier Semitic alphabetic script, to fashion the 22-letter alphabet that is still used, though with altered forms of the characters, by its sister language, Hebrew. It is the source of almost all other alphabets, and Homer's time corresponds to the period of its widespread adoption and modification by the Greeks for their language - between 800 and 700 BCE. There was a considerable corpus of historiography, though most has been lost: the main surviving work is the epitome by Philo of Byblos in Greek of the cosmology and history of Sanchuniathon (ca. $10^{\text {th }}$ century BCE) $[6, \text { p. 28 }]^{14}$. We have the Periplus, the dramatic narrative by a Carthaginian admiral, Hanno, of his exploratory sea voyage around Africa, but only in Greek translation. There are numerous inscriptions of all periods, many bilingual, in the 22-letter alphabet, reflecting the status for several centuries of Phoenician as a lingua franca of Western Asia and the eastern Mediterranean, Finally, Prof. Charles Krahmalkov has identified a late Punic praise poem whose parallelisms make it akin to the Hebrew poetry of over a millennium earlier ${ }^{15}$. This would argue, in favor of the case

${ }^{13}$ By the near other I mean a person whose culture and identity are markedly different from one's own, but who does not live faraway and is thus also familiar, the familiarity and proximity often generating unease and hostility. For Europeans this was the Jew; for the Greeks of Constantinople and the later Turks, the Armenian (see [9]); and for the Hellenes of Homer's time, I suggest, the Phoenician. I. Winter suggests that the Phoenicians of the historical Homer's time (that is, the mid-8th century BCE) might even have served as the model for an emerging urban and mercantile society in Greece, though they were still the "other" to the aristocratic ideal of the epic [4, p. 633].

14 For an edition and detailed study of Philo of Byblos see [10].

15 See [11]. 
I am about to make, for the conservatism of Phoenician writing, and the long memory of particulars of literary plot and style.

There seems to have been some imaginative romantic and adventure literature, if indeed one can claim a native source for the Hellenistic novella Phoenicica of Lollianus: Graham Anderson has adduced ancient Near Eastern parallels, that he argues were in some instances sources, for such Greek exotica. Parts of the Phoenicica survive as papyrus fragments from the second century CE; and a long, complete version, "The Tale of the Jewish Doctor", is found in the Arabic A Thousand Nights and a Night, indicating wide popularity over a period of a millennium. It is not a particularly edifying tale, with plenty of steamy sex, and at one point the villains murder a child as a sacrifice and eat cooked bits of it [12, p. 152-159] ${ }^{16}$. This may perhaps be an authentic echo, bent to narrative purposes, of the ubiquitous molk rite, a unique and enduring feature of Canaanite religion that horrified other peoples, ${ }^{17}$ though Anderson does not suggest it. And the ancient Greek novels are as sanguinary as they are erotic. But if the murder of a boy in Lollianus' sesterce-dreadful is a genuine Punic touch, then perhaps there was an earlier Phoenician text.

\section{A Phoenician tale}

Let us now turn to three texts whose plots have much in common with that of the $\mathrm{Od}$ yssey of Homer: a man travels over the seas for many years to reunite his sundered family, with scenes of recognition and of restoration of name and identity. I do not mean to suggest that these motifs, and others related to them, were peculiar to Phoenicia or originated there ${ }^{18}$; but as we have seen, the Phoenicians were the foreign people closest to Homer

16 The surviving Greek fragments of the Phoenicica were translated into English, with notes and bibliography, by G. N. Sandy in [13, p. 809-812].

17 The Phoenician and Carthaginian nobility offered their own infants to be immolated in sacrifice (the molk, which has come into English as Moloch) and buried in urns, with commemorative steles. The place where all this was done, is known from the Hebrew (of the Prophets who execrated it) as the tophet. There are tophets everywhere the Phoenicians settled; but the largest is the Precinct of Tanit at Salammbo in Carthage, where some 20000 funerary urns have been found [6, p. 245]. The Romans outlawed the practice but it persisted down to at least the 2 nd century CE (see [14]). Queen Jezebel introduced the Tyrian form of the rite in the valley (Hebrew ge) of Hinnom of evil fame near Jerusalem (thus subsequent Gehenna), but it has precursors in Israelite religion: the 'Aqedah ("Binding of Isaac") in Genesis and Jephthah's sacrifice of his own daughter. The sacrifice of God's only Son, whose followers drink His blood and eat His body for their salvation, might be skeptically regarded as in a way the last and greatest molk of Northwest Semitic religion, though the faith with this rite at its historical core is so universal as not to occasion surprise, much less revulsion. In medieval and later literary Hebrew, tophet even becomes a term for hell, even as Eden is used for the paradise of the world to come (see $[15$, p. 96, 106]). But it is interesting to observe that the baseless Christian blood libels against the Jews - according to which Christian children are kidnapped and their blood used to bake Passover matzah - may be the projection of an underlying anxiety about the strangeness of human sacrifice onto Christ's own people, where such practices were attested but rarely and in the archaic era, and were shunned many centuries before the Nativity. The latest court cases of the blood libel were of Mendel Beilis (acquitted of all charges in court at Kiev, on the eve of the First World War) and Leo Frank (arrested, tried, and lynched by a mob in Atlanta, Georgia, USA in 1915). The anti-Semitic blood libel is still broadcast as truth on television shows in Syria, Egypt, and other Islamic countries.

18 S. Thompson [16], for instance, notes motifs encountered in the folk-lore of diverse peoples of the quest for a lost or kidnapped family or particular relatives (H 1385), of families accidentally reunited after a wife is, for instance, kidnapped by a sea captain, with tests of identity [cf. Penelope and the bed] and scenes of recognition [cf. Eurycleia and Odysseus' scar] (N 730: from Buddhist texts to Boccaccio!), a man's return home in humble disguise [cf. Odysseus with Eumaeus] (K 1815.1), a guest in disguise under a false name [cf. Odysseus in Phaeacia] (P 322.2), etc. G. K. Gresseth [17] (for this reference I am indebted to Hannibal 
and his Odysseus, and as merchants and seafarers theirs was the culture most relevant to the main themes of Odysseus' life story. From the pen of earliest of the Roman dramatists, Plautus (b. ca. 254 BCE), comes the play Menaechmi ("The Two Menaechmuses"): A Sicilian (Sicily was heavily colonized by Phoenicians) has twin sons. He dies of grief after one is kidnapped; and the boys' maternal grandfather who raises the other, named Menaechmus, gives the name of the abducted boy, also Menaechmus, to the one still at home, whose original name was Sosicles. This Sosicles sets out to look everywhere for his twin, and sails for six years. The play starts at the end of that time: he casts anchor in the port of Epidamnus, where as it happens his kidnapped brother has been raised. This Epidamnian Menaechmus has prospered and has a hanger-on (parasitus) named Peniculus. The name of the latter means "little brush", one who sweeps up crumbs - which is what a parasitos does (the Greek means one who exchanges flattery, conversation, etc. for bread). But it can have obscene overtones, since the word can be read also as "little penis". And it may have been heard as well as a kind of epi-pun, perhaps, on Poenulus, "little Phoenician" - the name of the second play of Plautus we are presently to consider. The visitor is taken for his brother, who has planned to meet his favorite whore, Erotium, for lunch, and through a Comedy of Errors (indeed, the name of Shakespeare's play based on Plautus!) the brothers are reunited. So the sexual power of woman, so sinister in the Odyssey, is here the occasion for the favorable conclusion. It is a good story, and Ben Edwin Perry suggested that it and the ancient novel Apollonius, Prince of Tyre (note the Phoenician setting) served as the likely sources for the composition of the Pseudo-Clementine Recognitions, which we will consider once we are done with Plautus.

Is there anything Phoenician about the Menaechmi? The name Menaechmus is elsewhere attested only once in Greek, as that of a mathematician, a pupil of Eudoxus and friend of Plato, ca. 350 BCE. There is no known etymology, but I would like to propose one here. The name mnhm, vocalized Menahèm in Hebrew and hypothetically as Menehem in Phoenician, means "comforter". It is well attested: from Kition, $4^{\text {th }}$ century BCE, we find it in an inscription of Ariš, grandson of one Menehem, $r b$ srsrm "chief of the brokers" (a long line of ancestors with the same title is listed); from Tamassos, Cyprus, 363 BCE, a monument $(\mathrm{sml})$ is erected by Menehem son of Ben Hadaš son of Menehem ${ }^{19}$. The meaning of the name, "comforter", seems singularly appropriate for the characters of Plautus' play, who are tragically parted and happily reunited. By contrast, in megillät Eikhāh (the scroll of Lamentations), a text mourning the loss of the first two Temples, èin menahẹm läh, "there is no comforter for her" (i.e., Zion, Jerusalem) is a constant refrain. (But the Prophet Isaiah 40.1 also encourages us, Nahami 'amī, "Take consolation, O my nation!") As we can see from the Phoenician inscription from Tamassos, it was not unusual for the name to be used multiple times in a family over the generations, just as it is in Plautus' play. It is as extremely rare a name in Greek and Latin, as nominal derivatives of the root $n h m$ are common in Hebrew, from Biblical times down to the present day: Menachem, Nahum, Nachman, and Nechama. The proposed etymology of Menaechmus forces one, if the meaning of the name is of sig-

Taubes at the University of California, Berkeley). He also adduces a long parallel Indian tale to the Odyssey, embedded in a classical epic, that is close in both general structure and in some, though far from all, details. The relation between the two clearly cognate texts is impossible to define, but we may be fairly certain at least that India was not the source of the Homeric narrative, which displays, in Gressen's view, some basic "non-Indo-European" traits.

19 See $[18$, p. $70-71,88-89]$ and $[19$, p. 141]. 
nificance to the play (as is often the case), to ask also whether Plautus' play might even had had a Punic precursor whose audience understood the name.

And this leads us to the consideration of Plautus' second play, whose name and content leave no room for doubt as to its connection with Phoenicia: Poenulus ("the little Phoenician boy"), parts of which are in Punic transcribed into Latin script ${ }^{20}$. A sevenyear-old boy, Agorastocles, is kidnapped from Carthage. His father names a cousin, Hanno, his heir, and dies of grief. Hanno has two daughters. An old woman-hater, Antidamas (who as it turns out was a family friend) buys the boy, adopts him, and makes him his heir. Later the two girls are kidnapped also at Megara, a park outside Carthage, and one Lycus ("Wolf") purchases them. Our little Phoenician has grown into a strapping youth who falls in love with one of the two young ladies. Lycus torments him, but the frustrated swain manages to implicate the villain in an act of theft. Hanno the Carthaginian, who has been searching everywhere by sea and land for his lost daughters, finds the suitor to be his long lost nephew Agorastocles, and then recognizes the girl as well. The family are happily reunited, with a wedding as icing to the cake. Hanno is portrayed, not only as a dedicated family man ready to travel for years to find his lost relatives, but as a savvy cosmopolitan who "knows all languages, too, but dissembles what he knows - a total Carthaginian. Why say more?" (lines 104-113); polytropos, polymētis, polyglot - a complete Odysseus, too. The play is so similar to the Menaechmi that they seem to emanate from a single source, from the treasure house of stories and shared concerns of the same group of people. This play is known to be a translation of a lost Greek work, Karkhèdonios, "The Carthaginian", ca. 309-308 BCE, but we do not know whether the original had lines of Punic in it interspersed with the rest of the text, as here ${ }^{21}$. Krahmalkov ${ }^{22}$ suggests, intriguingly, that Plautus had at his disposal a Punic version of the Carchedonius and interwove lines from it with the Latin of his translation from the Greek. That means the Carthaginians would not only have had a theatrical culture, but enjoyed performances of Greek plays translated into their own language - a language that was evidently rich and capable of many kinds of literary genres and voices. Perhaps there was an original Punic play about members of a sundered family all named "Comforter", who were comforted.

The third text to be considered is the Pseudo-Clementine Recognitions (Greek Anagnōseis) ${ }^{23}$, for it, too, is novel of sea travel, of family members lost and found, and of Phoenicia - the genre has a convenient if ponderous generic brand name in German, Wiedererkennungsmärchen. Authorship was falsely attributed to Clement I, Bishop of Rome (late $1^{\text {st }}$ century CE; his Latin name means "calm, tranquil, gentle"); the work seems rather to be a document associated with the Ebionites or Nazoraeans. These were

20 For instance, avo doni "Live (long), sir!" (cf. Hebrew hai "live" and adōnī "my lord, mister"); mu punim sucartim, "Do you remember Punic?" (cf. Hebrew zākhartā, "you remembered"); and, poignantly, makom, literally "place", for "city" - the Jewish use of this word for Amsterdam became the slang name of the city in Dutch and is still used, even though some ninety percent of the Dutch Jews were murdered by the Nazis. As Hanno makes his entrance he prays (line 930) Yth alonim ualonuth sicorathi symakom syth, "Ye gods and goddesses that I call upon, of this place!" (Cf. Heb. 'elyōn "high [god]" and qarā'tī "I called").

21 On the face of it that would seem unlikely, given the deeply rooted Greek disdain for "barbarian" tongues. The early Romans were in a somewhat different position: many were at least bilingual to start with in Etruscan and the various Italic languages, and any man aspiring to even a smattering of culture had to learn Greek, which in any case was spoken all over southern Italy. And one had to know some Punic to travel do business in the western Mediterranean.

${ }^{22}$ See [20].

${ }^{23}$ See [21]. 
early Christians who accepted Jesus as a prophet or messiah but to varying degrees rejected the doctrines of the Pauline Christians whose version of the new faith was to become its self-proclaimed orthodoxy. Paul courted the gentiles and abandoned both the people of Israel and the laws of the Torah. One might go so far as to assert that Christian anti-Semitism was born with Paul's Epistles. The Ebionites and Nazoraeans did not break away, though, from the mother faith: they kept the Sabbath, the dietary laws of kashrut, circumcision, and other commandments. They also maintained steadfast attachment to the Land of Israel and reverence for Jerusalem as the place of the house of God on earth, the holy Temple. So it is reasonable to suppose that a story whose structure and themes are readily identifiable as belonging to the traditions of the Phoenicians, a people closely kin to the Jews, would have struck an instant resonance with them. Here is the story: Clement, the son of Faustus (a common Latin name meaning "fortunate"), has two brothers who are twins, Faustinus and Faustinianus (cf. the Menaechmi!) ${ }^{24}$. He lives in Rome with his parents and them, but one day the twins and their mother travel to Athens and mysteriously vanish. Clement later goes on a religious pilgrimage to see the Apostle Peter in the Land of Israel. They travel together to the isle of Arados (i.e., Arvad, off the Phoenician coast), where Peter meets a beggar woman. She tells him she left her home once with her twin sons to escape the lustful advances of her brother-in-law without bringing shame upon the family. She and her boys were parted in a shipwreck. Peter reunites Clement with his mother, and they proceed northwards along the coast, visiting the temple of Melqart at Tyre and eventually arriving at Antioch, where they meet Nicetas and Aquila - who are in fact Faustinus and Faustinianus. The two had been captured after the shipwreck that parted them from their mother, and were adopted and named by a kindly Jewish Christian, Justin, in Caesarea on the coast of Israel. Peter mentions several times in the text the mendacious doctrines of the bad man - Paul - so the story is used as a frame to propagate Jewish Christian teaching, and Peter and Justin, the righteous men of the piece, are made to be the instrument of the recognitions and reunions of the sundered family, mother, twins, and all. The name Clement to the ear of a Semitic speaker might well be understood as a Latin synonym of Menachem; but in any case we already have a play on names - twin boys and a dad all named "Lucky", which indeed the lads turn out to be, as their names and identity are restored.

\section{Conclusions, and a different future for Odysseus}

To review the evidence: we have the Odyssey of Homer, ca. $750 \mathrm{BCE}$; two similar Greek plays, one of which is securely Phoenician in its characters and setting, the other likely to be so, ca. $350 \mathrm{BCE}$ (later translated and reworked by Plautus); and a Jewish Christian novella clearly modeled on the same basic story of the two plays and set in the Land of Israel, Phoenicia, and up the Syrian coast, $c a .2^{\text {nd }}$ century CE. The two plays and the novel-

24 T.Hägg [22, p. 163], notes that the motif of the twins is entirely unexploited, which would suggest that the author "simply took over parts of a ready-made story" on which to erect the "superstructure" of his apologia for the Christian faith. I have argued that a propagandist of Manichaeism, probably around the same time $\left(3^{\text {rd }}-4^{\text {th }}\right.$ century CE), acted in much the same way- he appropriated the epic motifs of the heroic quest and Drachenkampf - battle with a dragon - and then cunningly altered aspects of them in order attract, disorient, then teach a Syro-Armenian audience (see [23]). If one recalls the episode of initiation into the cult of Isis in the Metamorphoses of Apuleius of Madaura ( $2^{\text {nd }}$ century CE) and considers Merkelbach's persuasive argument that Iamblichus worked Mithraic allegory into his own Oriental Hellenistic romance, the Babyloniaka, then the religious subtext seems more the rule than the exception in these popular works. 
la would appear to flow from the same stream of Phoenician storytelling, in overall theme and in small details such as naming, but they are attested at a minimum of four centuries after Homer. Moreover, one might expect to encounter the common story line among peoples who sailed the Mediterranean, without the necessity of filiation; and the themes and elements of the story can be found as folk-lore motifs in many places and times. So one cannot offer a watertight case. This is a skiff whose caulking Odysseus would not approve. Fortunately, even as Melqart rides his sea horse over the waves, the hero of Ithaca, so like the Tyrian Heracles in his trials of strength, could mount the floating planks of a shattered vessel. But one's suggestion of a much older Phoenician tale behind the plays, the novel - and the epic - given the circumstances of culture and geography, is something more than a thought experiment if less than a concrete archaeological excavation. It is a suggestion that is not at all an unreasonable one. And if we give it a hearing, then perhaps our understanding of the complexity of Greek identity itself may be enhanced. Man is both a single being and a binary, forked creature; our thoughts perpetual thesis and antithesis. Thus, too, the foundational, sacral epic of Hellenic civilization itself. Half is aristocratic, martial, landed, rooted in the rules of honor and shame, and imperishable glory, Achaean, Indo-European, chanted by bards. And the other half is writ in the script of Cadmus (Semitic qdm, "eastern, ancient"), and is clever, mobile, and febrile, cosmopolitan and adaptable, curious and adventuring, Phoenician, Semitic. One adumbrates here not only the cross-cultural borrowings admirably explored by Michael Astour in his Hellenosemitica, but the very sense of what it is to be Greek. The truly admirable is always also inexplicable; yet perhaps it was this merging of two streams of eastern Mediterranean civilization that was in part responsible for that synthesis: the golden age of Athens, the city whose goddess was patroness of Odysseus and Telemachus, the city where the written recension of Homer was accomplished.

In his famous poem Ithake the modern Greek poet Constantine Cavafy writes, "When you set out on the journey to Ithaca, / Pray that the road be long," full of adventures, new sights, discoveries, and luxurious, exotic things to enjoy. A less well-known verse published in the Mikra Kabaphika entitled Deutera Odysseia, "A Second Odyssey", with epigraphs from the $26^{\text {th }}$ canto of the Inferno of Dante and Alfred, Lord Tennyson's "Ulysses", suggests (lines 27-29) ...kai tèn eirēnēn kai anapausin tou oikou ebarynthē:/ K' ephygen "... and the peace and relaxation of home weighed upon him/ And he fled." Dante has Ulysses and his men sail through the Pillars of Hercules (i.e., of Tyrian Melqart) and turn south to discover what lies in the regions of the Antipodes. Ulysses urges them on with a short, stirring oration that must be seen as the noble battle cry of the Renaissance at its moment of birth: Considerate la vostra semenza:/ fatti non foste a viver come bruti, / ma per seguir virtute e canoscenza "Think of the seed from which you were born! / You were not made to live as animals, / but to pursue virtue and knowledge." But as the crew heave in sight of the mount of Purgatory, three great waves engulf them, punishing them for their hubristic audacity. Three waves, trikymia, is Greek for a storm at sea; and here the number must correspond to the Trinity as well. Tennyson's poem presents Ulysses in the same way, urging on his men with eloquence of equal might and passion: "It may be we shall touch the Happy Isles, / And see the great Achilles, whom we knew. / Tho' much is taken, much abides; and tho'/ We are not now that strength which in old days/ Moved earth and heaven, that which we are, we are;/ One equal temper of heroic hearts, / Made 
weak by time and fate, but strong in will/ To strive, to seek, to find, and not to yield." Is there a man, young or old, with such a heart of stone as to be unmoved by these lines?

Yet all the prediction in the Odyssey actually says is that our hero is to travel again, to a place where men do not know oars, and that death will come to him from the sea in a normal way. There is no suggestion that he will become bored and want to leave Ithaca, and there is no sequel either that might recount the fate of Telemachus. Western humanistic tradition has projected the fate of Odysseus in a direction never explicitly defined, in a mighty and audacious feat of imagination ${ }^{25}$. If the basic narrative frame, the armature, of the Odyssey is the Phoenician tale that I have proposed, then the later life and end of our hero can accordingly be imagined in another way than Dante and his successors envisioned it. His later life, following our model, would have been a time of domestic happiness and tranquillity, not a daring voyage of heroic discovery (or, viewed more cynically, a deadbeat dad's road trip with his pals to relive his youth). It is a future with Penelope and

${ }^{25}$ Joseph Brodsky tried to imagine it. Either the worst has happened, and the journey has blurred the consciousness and identity of Odysseus, or it is years later, and he is old and about to go away. Moŭ Телемак, / Троянская война окончена. Кто победил - не помню. / Должно быть, греки: столько мертвецов / вне дома бросить могут только греки..., / И все-таки ведущая домой / дорога оказалась слишком длинной, / как будто Посейдон, пока мы там / теряли время, растянул пространство. / Мне неизвестно, где я нахожусь, / что предо мной. Какой-то грязный остров, / кусты, постройки, хрюканье свиней, / заросший сад, какая-то иарииа, / трава да камни... Милый Телемак, / все острова похожи друг на друга, / когда так долго странствуешь, и мозг / уже сбивается, считая волны, / глаз, засоренный горизонтом, плачет, / и водяное мясо застит слух. / Не помню я, чем кончилась война, / и сколько лет тебе сейчас, не помню. // Расти большой, мой Телемак, расти. / Лишь боги знают, свидимся ли снова. / Ты и сейчас уже не тот младенеи, / перед которым я сдержал быков. / Когда 6 не Паламед, мы жили вместе. / Но, может быть, и прав он: без меня / ты от страстей Эдиповых избавлен, и сны твои, мой Телемак, безгрешны. "My Telemachus: / The Trojan war is over. Who won I don't remember. / It must have been the Greeks: only Greeks / could toss so many corpses out the door... / But the road leading home even so/ seems to have been too long, / As though Poseidon, while there / we wasted time, stretched space. / I don't know now where I am / Or what's in front of me. Some dirty isle, / bushes, houses, snorting pigs, / a garden overgrown, some queen, / and grass and stones... My dear Telemachus, / all islands are similar to each other, / when you've been wandering this long, and the brain / loses track counting waves; / the eye tears, clogged by the horizon, / and the flesh of the brine dulls the ear. / I don't recall how the war ended, / don't remember how old you are now. // Grow big, my Telemachus, grow. / Only the gods know if we'll meet again. / You aren't the baby anymore / Before whom I held the oxen back. / If not for Palamedes, we'd have lived together. / But perhaps he's right: without me / You're relieved of Oedipal passions, and your dreams, my Telemachus, are harmless." I sat a few feet from Brodsky as he recited this newly completed poem at a reading in the international studies building of Columbia University on a Spring afternoon in 1972, shortly after his expulsion from the Soviet Union. A freshman all of eighteen then, one did not yet know to ask him whether he meant that all islands are alike, like all Tolstoy's happy families; and had one known more then, one might have asked him, also, whether he intended his evocation of stretched space and wasted time in "Odysseus to Telemachus" to resonate in wan irony with the final verses of Mandelstam's poem of 1917 in Tristia, "The stream of honey golden from the bottle flowed": Помнишь, в греческом доме: любимая всеми жена, - / Не Елена - другая, - как долго она вышивала? / Золотое руно, где же ты, золотое руно? / Всю дорогу шумели морские тяжелые волны, / И, покинув корабль, натрудивший в морях полотно, / Одиссей возвратился, пространством и временем полный. "Do you recall, in that Hellenic house, the wife beloved of all, / Not Helen, the other, how long she was weaving? / Golden fleece, where are you then, golden fleece? / All the way thundered the heavy sea breakers, / And abandoning his ship, working a canvas of the waves, / Odysseus returned, replete with time and space." Brodsky was impatient with pedants in later years but he was still young then, and gentle with a boy: I approached him and asked whether he had read The Icon and the Axe; later, I gather, he and James Billington were friends. There is another Russian insight, cryptically brief but wonderfully pregnant with suggestion of the uncanny, into the character of Telemachus: in Vladimir Nabokov's novel Bend Sinister the hero, Professor Adam Krug, suggests that one read the "pruned" essence of the name TELMAH (i.e., Telemachus) backwards: the result is Hamlet. 
the growing Telemachus to comfort ( $n h m$ !) him and be comforted by his gentle presence as he grew old, not one of arms and warriors. So at some point towards the end, the aged Odysseus, king of a little island, set out on a distant journey on business: those Sidonians of ours were sailing through the Pillars of Melqart all the time, not to storm Purgatory but to trade in Cadiz and pick up cargo at the tin mines of southern Britain. And perhaps on just such a commercial voyage in the dangerous Atlantic he met his end. But for long years he had enjoyed a happy life at home reunited with his beloved wife and son. It was the life of peace that he worked so hard and prayed so long for, over ten long years of hard fighting under the walls of Troy and ten more of harder sailing - peace that he deserved, and, with the aid of his friend, the grey-eyed goddess Athena, finally got. It's about family.

\section{References}

1. Russell J.R. "The Cat Who Played Dead" (translation of a poem by Naghash Hovnatan, with commentary). Ararat Quarterly, vol. 32, Summer 1992, no. 131.

2. Halbertal M. People of the Book: Canon, Meaning, and Authority. Cambridge, MA, Harvard University Press, 1997. $208 \mathrm{p}$.

3. Russell J. R. A Parthian Bhagavad Gita and its Echoes. Eds J.-P. Mahé, R. W. Thomson. From Byzantium to Iran: In Honour of Prof. Nina Garsoian. Atlanta, Scholars Press, 1996, pp. 17-35.

4. Winter I. J. "Homer's Phoenicians: History, Ethnography, or Literary Trope? (A Perspective in Early Orientalism)", reprinted in her On Art in the Ancient Near East, Vol. I: Of the First Millennium BCE, Leiden, Brill, 2010, pp. 597-639.

5. Russell J.R. Argawan: The Indo-European Memory of the Caucasus. Journal of Armenian Studies, vol. III. 2, Fall, 2006 [2007], pp. 110-147.

6. Aubet M. E. The Phoenicians and the West: Politics, Colonies, and Trade, $2^{\text {nd }}$ ed. Cambridge, Cambridge University Press, 2001. 432 p.

7. Krahmalkov C. R. Phoenician-Punic Dictionary (Orientalia Lovaniensia Analecta 90; Studia Phoenicia 15). Leuven, Peeters, 2000. 499 p.

8. Muhly J.D. Homer and the Phoenicians: The Relations between Greece and the Near East in the Late Bronze and Early Iron Ages. Berytus, 1970, vol. 19, pp. 19-64.

9. Russell J. R. A Scholium on Coleridge and an Armenian Demon. Journal of the Society for Armenian Studies, vol. 10 (1998, 1999, [2000]), pp. 63-71.

10. Baumgarten A. I. The Phoenician History of Philo of Byblos: A Commentary. Leiden, Brill, 1981. $284 \mathrm{p}$.

11. Krahmalkov C. R. 'When He Drove out Yrirachan': A Phoenician (Punic) Poem, ca. A.D. 350. Bulletin of the American Schools of Oriental Research, no. 294 (May, 1994), pp. 69-82.

12. Anderson G. Ancient Fiction: The Novel in the Greco-Roman World. London, Croom Helm, 1984. $248 \mathrm{p}$.

13. Reardon B.P. Collected Ancient Greek Novels. Berkeley, Los Angeles, University of California Press, 1989. $827 \mathrm{p}$.

14. Brown S. Late Carthaginian Child Sacrifice and Sacrificial Monuments in their Mediterranean Context (JSOT/ASOR Monograph Series, vol. 3). Sheffield, Sheffield Academic Press, 1991. 335 p.

15. Roth C. The Jews in the Renaissance. Philadelphia, The Jewish Publication Society of America, 1959. $426 \mathrm{p}$.

16. Stith Thompson S. Motif-Index of Folk-Literature, in 6 vols. Bloomington, IN, Indiana University Press, 1955-1958.

17. Gresseth G.K. The Odyssey and the Nalopäkhyāna. Transactions of the American Philological Association, 1979, vol. 109, pp.63-85.

18. G. A. Cooke. A Text-Book of North Semitic Inscriptions. Oxford University Press, Oxford, UK, 1903. $472 \mathrm{p}$.

19. Benz F. L. Personal Names in the Phoenician and Punic Inscriptions. Rome, Biblical Institute Press, 1972. $511 \mathrm{p}$.

20. Krahmalkov C.R. Observations on the Punic Monologues of Hanno in the 'Poenulus'. Orientalia, New Series, 1988, vol. 57, no. 1, pp. 55-66.

21. Irmscher J., Strecker G. The Pseudo-Clementines. Ed. by Wm. Schneemelcher. New Testament Apocrypha, vol. II. Louisville, KY, James Clarke \& Co., Westminster, John Knox, 1992, pp. 483-530. 
22. Hägg T. The Novel in Antiquity. Berkeley and Los Angeles, University of California Press, 1983. 264 p.

23. Russell J. R. The Epic of the Pearl. Revue des Etudes Arméniennes, 2001-2002, vol. 28, pp. 29-100.

Received: 12.11 .2017

Accepted: 08.02.2018

Author's information:

James R. Russell — PhD, Professor; russelldeep@gmail.com

\section{Одиссей и финикийская сказка}

\section{Джеймс Р. Рассел}

Гарвардский университет, Массачусетс Холл, Кембридж, МА 02138

Для цитирования: Russell J. R. Odysseus and a Phoenician tale // Вестник Санкт-Петербургского университета. Философия и конфликтология. 2018. Т. 34. Вып. 2. С. 233-250. https://doi. org/10.21638/11701/spbu17.2018.208

Вопрос об авторстве двух гомеровских эпосов - принадлежит ли Гомеру только один из них или оба - был трудным для ученых с момента начала их критического литературного исследования. Отличающаяся воинственным духом, но в меньшей степени психологизированная и таинственная «Илиада», безусловно, была более популярной поэмой в древности. И хотя позднее в «Энеиде» Вергилий сумел тенденциозно объединить историю о воинской доблести с сюжетом возвращения на родину, перед читателем предстал воспетый римским поэтом воин - человек оружия, а не человек многих путей и уловок. Автор статьи утверждает, что Одиссея с его гибкостью и приспособляемостью к обстоятельствам можно сравнить с ханаанским (финикийским) купцом-путешественником. Одиссей - «бескорыстный космополит» своей бесконечно удаленной от нас эпохи - резонирует затруднительному положению отчуждения современного человека и психологической глубине современной литературной чувствительности гораздо больше, чем воинственный, откровенный, ограниченный Ахиллес или Эней. В статье выдвигается гипотеза о том, что «Одиссея» Гомера использует топос человека, странствующего в поисках потерянных членов своей семьи, причем путешествие завершается счастливым концом. Этот топос, по-видимому, был особенно популярен на протяжении многих веков у финикийцев и карфагенян. Автор утверждает, что за именем Менехма - персонажа основанной на этом топосе пьесы Плавта «Два Менехма», пуническая постановка которой могла быть осуществлена в Кварте Хадаште (в новом городе, т. е. в Карфагене) в северо-западном семитском переводе, с очевидностью просматривается очень распространенное еврейское имя Менахем. Опираясь на обширный сравнительно-лингвистический материал, автор отмечает повторяемость топов (общих мест) данного сюжета, использовавшихся в религиозной пропаганде иудео-христиан в частности в «Псевдо-Клементинах» - апокрифических текстах, в которых описывается морское путешествие обращенного язычника (предположительно, св. Климента Римского) с ап. Петром.

Ключевые слова: литература, сказка, культура, человек, топос, христианство, язычество.

Контактная информация:

Рассел Джеймс P. — д-р филос. наук, проф.; russelldeep@gmail.com 